\title{
A review of Human Immunodeficiency Virus (HIV) rapid testing
}

\author{
Ha $S^{1^{*}}$, Foley $S^{1}$, Paquette $D^{1}$, Seto $J^{1}$ \\ ${ }^{1}$ Centre for Communicable Diseases and Infection Control, Public Health Agency of Canada, Ottawa, ON \\ *Corresponding author: shalane.ha@phac-aspc.gc.ca
}

\section{Abstract}

Background: In Canada, it is estimated that 71,300 persons were living with HIV at the end of 2011. Approximately $25 \%(14,500$ to 21,500$)$ of prevalent cases were unaware of their HIV infection. Expanded use of HIV rapid tests may increase the detection of undiagnosed infections, enable earlier treatment and support services and prevent the onward transmission of HIV.

Objective: To examine patient acceptability, impact (defined as receipt of test results and linkage to care) and cost-effectiveness of HIV rapid tests.

Methods: A search was conducted for systematic reviews on HIV rapid testing, with studies from both developed and developing countries, published in English and between 2000 and 2013. The Assessment of Multiple Systematic Review (AMSTAR) tool was used to assess the included systematic reviews for methodological quality. Results were summarized narratively for each of the outcomes.

Results: Eight systematic reviews were included. Acceptability of HIV rapid tests was generally high in medical settings $(69 \%$ to $98 \%)$ especially among pregnant women and youth attending emergency rooms but was lower in non-medical settings ( $14 \%$ to $46 \%)$. The percentage of people who obtained their test results was variable. It was high $(83 \%$ to $93 \%)$ in emergency rooms but was low in a rapid care setting with regular business hours $(27 \%)$. Impact on linkage to care was limited. Only one systematic review examined cost-effectiveness of rapid testing and concluded that HIV rapid tests were cost-effective in comparison to traditional methods; however, results were all based on static models.

Conclusion: Overall, HIV rapid tests demonstrated generally high acceptability, variability in receiving test results and limited impact on linkage to care. While these findings suggest that HIV rapid tests may be useful, further research is needed to confirm in whom, when and where they are best used and how to ensure better linkage to care.

\section{Introduction}

At the end of 2011, an estimated 71,300 persons were living with Human Immunodeficiency Virus (HIV) and Acquired Immunodeficiency Syndrome (AIDS) in Canada and an estimated $25 \%$ were unaware of their HIV status (1). Those unaware of their status are unable to take advantage of available support services and care, are at increased risk of transmitting HIV and are at increased risk of acquiring other sexually transmitted and bloodborne infections. Effective screening strategies that lead to earlier diagnosis and treatment can contribute to improved individual and population health outcomes (2).

With the emergence of new diagnostic technologies, there are increasing options for HIV testing. Rapid tests for HIV are available worldwide including oral fluid tests and finger prick tests using whole blood or plasma. HIV rapid tests can be either self-administered or administered by trained staff. In Canada, HIV rapid tests can only be carried out by trained staff in point-of-care (POC) settings (e.g., doctors' offices, clinics, emergency departments) (3-5). In addition, the Public Health Agency of Canada recommends that HIV rapid tests be administered in conjunction with pre- and post-test counselling (5). 
Only one HIV rapid test is licensed for use in Canada (6). In October 2005, Health Canada approved the INSTI ${ }^{\mathrm{TM}}$ HIV-1 Antibody Test (a single use rapid test for HIV) for use in POC settings. In 2008, the license was amended to include the INSTI TM HIV-1/HIV-2 Antibody Test (6). This test is a preliminary antibody screening test that can be performed on site where the patient can receive their results immediately $(<1 \mathrm{hr})(7-10)$. If the patient receives a preliminary reactive result, a confirmatory test using traditional laboratory-based testing is required. If the test result is negative (non-reactive), no further testing is necessary $(3,5)$.

Previous studies suggest POC testing has the potential to improve the management of infectious diseases by identifying new infections, reducing the numbers of those who are unaware and facilitating linkage to care $(11,12)$. To ensure HIV rapid tests are feasible, they should also be cost-effective. The objective of this rapid review was to examine the most current evidence on patient acceptability, impact (defined as receipt of test results and linkage to care) and cost-effectiveness of HIV rapid tests.

\section{Methods}

We followed the Ottawa Hospital Research Institute's methods for conducting rapid reviews (13). This method is designed to provide decision-makers with a synthesis of an extensive literature in a timely manner (13). A protocol was developed for the rapid review a priori that included: question development and refinement; a systematic literature search; screening and selection of systematic reviews; assessing the quality of the evidence; and a narrative synthesis of included studies. (13).

\section{Search strategy}

The following databases were searched: Medline, Embase, Scopus, Social Policy and Practice, Proquest Public Health and Google Scholar. Articles were included if they were published between January 2000 and September 2013; included studies from developed or developing countries; and/or published in English. The search strategy included the following key words: ("human immunodeficiency virus" OR "HIV") AND ("Point of care" OR "point-ofcare", "rapid test" OR "home-based test" OR "screen*") AND ("linkage to care" OR "follow-up" OR "barrier", "intervention*" OR "access"” OR "diagnos*”) OR ("acceptab*”, "willing", "satisf", "preference*”) OR ("feasib", "economic", "financ", "cost"). Articles that reported results on HIV prevalence or studies with no mention of HIV rapid testing were excluded from the review.

\section{Quality assessment of the studies}

Each systematic review was evaluated using the Assessment of Multiple Systematic Review (AMSTAR) tool for methodological quality (14). The AMSTAR tool consists of an 11-item questionnaire that assesses the following criteria: use of an a priori design; duplicate study selection and data extraction process; comprehensive literature search; use of publication status as an inclusion criterion; characteristics of included studies; list of included / excluded studies; assessment of the quality of studies; appropriate use of scientific quality in forming conclusions; appropriate methods used to combine study findings; assessment for publication bias; and acknowledgement of conflict of interest. To ensure reliability of the assessment, two of the authors (SH, SF) evaluated the systematic reviews using the AMSTAR tool. Where there was discrepancy, a third person (DP) was invited to assess the criterion in question.

\section{Data extraction}

For each of the included systematic reviews, two authors (SH, SF) extracted data on population; search years; number of included studies; locations of included studies; study objective; type of intervention; and outcomes. Outcomes of interest included: acceptability, receipt of HIV test results, linkage to care and cost-effectiveness. After data extraction, both authors compared their findings to ensure consistency.

\section{Results}

The initial search yielded a total of 892 articles on rapid testing for HIV. After limiting to systematic reviews $(n=12)$, eight review articles met the inclusion criteria (Figure 1). 
Figure 1: Algorithm of literature search and study selection of systematic reviews on rapid HIV testing

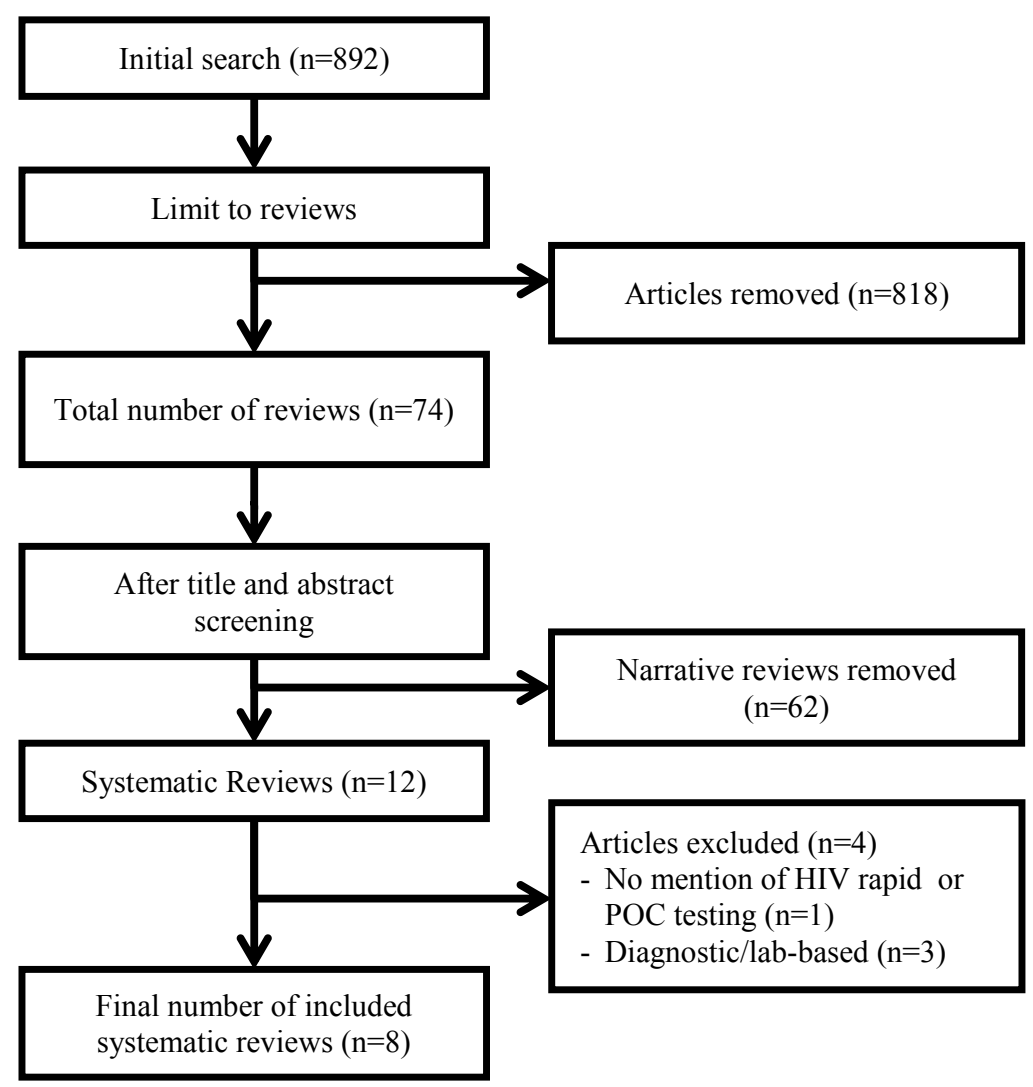

A description of the included reviews and the respective AMSTAR score out of 11, are presented in Table 1. Three had perfect AMSTAR scores and another was of high quality (with a score of 8 ). Reasons for a systematic review having a score less than eight included: it did not specify a duplicate study selection and data extraction process; assessment and documentation of the quality of the studies; or assessment of publication bias. 
Table 1: Description of included systematic reviews with the AMSTAR ${ }^{1}$ scores

\begin{tabular}{|c|c|c|c|c|}
\hline Reference & Objective(s) & $\begin{array}{l}\text { Population and } \\
\text { location }\end{array}$ & $\begin{array}{c}\text { Search period, } \\
\text { intervention and } \\
\text { number of included } \\
\text { studies }\end{array}$ & $\begin{array}{l}\text { AMSTAR } \\
\text { score } \\
\text { (out of 11) }\end{array}$ \\
\hline $\begin{array}{l}\text { Bateganya } \\
(2007)(17)\end{array}$ & $\begin{array}{l}\text { To identify and critically appraise } \\
\text { studies addressing the } \\
\text { implementation of home-based } \\
\text { HIV voluntary counselling and } \\
\text { testing; to assess the effect of this } \\
\text { intervention compared to facility- } \\
\text { based HIV counselling and } \\
\text { testing. }\end{array}$ & $\begin{array}{l}\text { Population: Adults } \\
\text { (>15 years) } \\
\text { Location(s): Uganda } \\
\text { and Zambia }\end{array}$ & $\begin{array}{l}\text { Search period: } 1980 \text { - } \\
2007 \\
\text { Intervention: Voluntary } \\
\text { counselling and testing } \\
\text { for HIV } \\
\text { No. included studies: } 2\end{array}$ & 11 \\
\hline $\begin{array}{l}\text { Bateganya } \\
(2010)(8)\end{array}$ & $\begin{array}{l}\text { To establish the effect of home- } \\
\text { based HIV voluntary counselling } \\
\text { and testing on uptake of HIV } \\
\text { testing. }\end{array}$ & $\begin{array}{l}\text { Population: Adults } \\
\text { (>15 years) } \\
\text { Location(s): Zambia }\end{array}$ & $\begin{array}{l}\text { Search period: } 2007 \text { - } \\
2008 \\
\text { Intervention: Voluntary } \\
\text { counselling and testing } \\
\text { for HIV } \\
\text { No. included studies: } 1\end{array}$ & 11 \\
\hline $\begin{array}{l}\text { Dibosa-Osadolor } \\
(2010)(21)\end{array}$ & $\begin{array}{l}\text { To review evidence used to derive } \\
\text { estimates of cost-effectiveness of } \\
\text { HIV screening and to appraise the } \\
\text { methodologies of economic } \\
\text { studies of HIV screening. }\end{array}$ & $\begin{array}{l}\text { Population: Various } \\
\text { Location(s): Not } \\
\text { stated }\end{array}$ & $\begin{array}{l}\text { Search period: } 1993 \text { - } \\
2008 \\
\text { Intervention: Economic } \\
\text { modelling of HIV } \\
\text { screening and testing } \\
\text { programs } \\
\text { No. included studies: } \\
17\end{array}$ & 7 \\
\hline $\begin{array}{l}\text { Napierala } \\
\text { Mavedzenge } \\
(2013)(18)\end{array}$ & $\begin{array}{l}\text { To conduct a review of policy and } \\
\text { research on HIV self-testing. }\end{array}$ & $\begin{array}{l}\text { Population: Various } \\
\text { Location(s): Kenya, } \\
\text { Zambia, United } \\
\text { States, Singapore, } \\
\text { South Africa, } \\
\text { Germany, Malawi, } \\
\text { Netherlands, United } \\
\text { Kingdom, France }\end{array}$ & $\begin{array}{l}\text { Search period: } 1980 \text { - } \\
\text { May } 2012 \\
\text { Intervention: HIV self- } \\
\text { testing } \\
\text { No. included studies: } \\
24\end{array}$ & 6 \\
\hline $\begin{array}{l}\text { Pant Pai (2007) } \\
\text { (15) }\end{array}$ & $\begin{array}{l}\text { To summarize the overall } \\
\text { diagnostic accuracy of rapid HIV } \\
\text { tests in pregnancy; evaluate } \\
\text { outcomes and impact of testing; } \\
\text { and identify practical challenges } \\
\text { related to the implementation of } \\
\text { voluntary HIV testing and } \\
\text { counselling in pregnant women. }\end{array}$ & $\begin{array}{l}\text { Population: Pregnant } \\
\text { women (18 to } 44 \\
\text { years) } \\
\text { Location(s): South } \\
\text { Africa, United States, } \\
\text { Latin America, South- } \\
\text { East Asia, Jamaica }\end{array}$ & $\begin{array}{l}\text { Search period: } 1991 \text { - } \\
\text { July } 2005 \\
\text { Intervention: HIV POC } \\
\text { testing in pregnancy } \\
\text { No. included studies: } \\
17\end{array}$ & 8 \\
\hline $\begin{array}{l}\text { Pant Pai (2013) } \\
\text { (9) }\end{array}$ & $\begin{array}{l}\text { To review supervised and } \\
\text { unsupervised self-testing } \\
\text { strategies for HIV. }\end{array}$ & $\begin{array}{l}\text { Population: Various } \\
\text { Location(s): United } \\
\text { States, Canada, } \\
\text { Singapore, India, } \\
\text { Malawi, Spain, Kenya, } \\
\text { Netherlands }\end{array}$ & $\begin{array}{l}\text { Search period: January } \\
2000 \text { - October } 2012 \\
\text { Intervention: } \\
\text { Supervised and } \\
\text { unsupervised HIV POC } \\
\text { testing } \\
\text { No. included studies: } \\
21\end{array}$ & 11 \\
\hline
\end{tabular}




\begin{tabular}{|c|c|c|c|c|}
\hline $\begin{array}{l}\text { Roberts (2007) } \\
(16)\end{array}$ & $\begin{array}{l}\text { To review the outcomes of blood } \\
\text { and oral fluid rapid HIV testing. }\end{array}$ & $\begin{array}{l}\text { Population: Various } \\
\text { Location(s): United } \\
\text { States, Kenya, Brazil, } \\
\text { Zimbabwe, Burkina } \\
\text { Faso, Mexico }\end{array}$ & $\begin{array}{l}\text { Search period: January } \\
2000 \text { - June } 2006 \\
\text { Intervention: HIV rapid } \\
\text { testing } \\
\text { No. included studies: } \\
26\end{array}$ & 4 \\
\hline $\begin{array}{l}\text { Turner }(2013) \\
(19)\end{array}$ & $\begin{array}{l}\text { To review preferences and } \\
\text { acceptability of rapid POC testing } \\
\text { in youth, to document notification } \\
\text { rates and to identify socio- } \\
\text { demographic factors associated } \\
\text { with youth choosing rapid HIV } \\
\text { POC testing over traditional } \\
\text { testing. }\end{array}$ & $\begin{array}{l}\text { Population: Youth } \\
\text { (<25 years) } \\
\text { Location(s): United } \\
\text { States }\end{array}$ & $\begin{array}{l}\text { Search period: January } \\
1990 \text { - March } 2013 \\
\text { Intervention: HIV POC } \\
\text { testing } \\
\text { No. included studies: } \\
14\end{array}$ & 7 \\
\hline
\end{tabular}

${ }^{1}$ AMSTAR $=$ Assessment of Multiple Systematic Review (AMSTAR) is a tool used to assess the methodological quality of systematic reviews

'This review included one study as it was an update to the Bateganya (2007) Cochrane review.

\section{Acceptability}

Almost all of the reviews (7/8) examined acceptability. Acceptability was defined in these reviews as the population's uptake of a rapid test $(8,9,15-17)$ or as the patient's preference for a rapid test when offered the choice of a rapid test or traditional laboratory-based test $(18,19)$.

In the Roberts et al. review, the overall acceptability of rapid tests administered in both medical and community settings ranged from $14 \%$ to $98 \%$ (16). Acceptability of rapid testing was lower (14\% to $46 \%$ ) in alternative testing sites (e.g., bathhouses, needle exchange programs, jails and emergency departments) compared to medical settings (69\% to $98 \%$ ) (e.g., sexually transmitted infection clinics, labour and delivery units and hospitals) (16). The wide range of acceptance rates may have been affected by differences in the definition of acceptability and in the data collection methods.

In two reviews, acceptability for HIV rapid tests was high among pregnant women $(15,16)$. In the Pant Pai et al. review, acceptability among pregnant women ranged from $83 \%$ to $97 \%$ (15). Similarly, in the Roberts et al. review, acceptability among pregnant women ranged from $74 \%$ to $86 \%$ in American studies and from $93 \%$ to $98 \%$ in international studies (16). Among pregnant women, the following factors were associated with high acceptability of HIV rapid testing: age (<21 years), higher education and lack of appropriate prenatal care during pregnancy (15).

Among the youth, Turner et al. found that $35 \%$ to $93 \%$ accepted HIV rapid tests when offered. The $35 \%$ acceptance rate was found in an adolescent outpatient clinic (19). However, when given the option of rapid or traditional methods, youth from the adolescent outpatient clinic selected rapid methods $70 \%$ of the time (19). The highest acceptance rates ( $83 \%$ to $93 \%$ ) were found in emergency rooms suggesting that there is high acceptability for rapid testing among youth attending emergency departments (19).

In the Mavedzenge et al. review, acceptability was defined as the interest to self-test. Among key populations such as men who have sex with men (MSM) and emergency department attendees, the authors found that acceptability of self-testing was moderate to high (62\% to $92 \%)(18)$. Reasons for preferring self-testing included privacy, autonomy, confidentiality, anonymity, convenience and speed.

Pant Pai et al. demonstrated that acceptability (choosing self-testing over the traditional laboratory-based tests) was high in supervised and unsupervised settings (9). In supervised settings, there was high acceptability (74\% to $96 \%$ ) among emergency department attendees, urban MSM, university students and the general urban population. Of note, an older study from 2001 reported an acceptance rate of $24 \%$ among HIV clinic attendees. In unsupervised settings, the high acceptability (74\% to $84 \%$ ) was only based on two studies, which focused on healthcare professionals and HIV negative MSM (9).

Acceptability of HIV rapid tests was variable across different populations, but was generally high among pregnant women, youth attending emergency rooms and in medical settings. More research is needed to explore selftesting in unsupervised settings and reasons for low acceptance rates in non-medical settings. 


\section{Receipt of HIV test results}

Four of the eight (4/8) systematic reviews examined the impact of HIV rapid testing on patients' receipt of test results. One systematic review by Roberts et al. noted that $27 \%$ to $100 \%$ of clients who attended medical and community settings for rapid testing received their HIV test results (16). The low rate of $27 \%$ was when same day results were available in an urgent care clinic with regular business hours and most participants left before the results were available (20). In the remaining studies, more than $70 \%$ of participants who underwent rapid testing at hospitals, sexually transmitted infection clinics, homeless shelters and bathhouses received their test results (16).

In a review by Bateganya et al., those who received voluntary counselling and testing (with rapid tests) at home were approximately five times more likely to receive their test results compared with those who received voluntary counselling and rapid testing at a clinic (17). The authors conducted an updated review that included one additional study, and found that $56 \%$ of individuals who had the home-based testing received their test results compared to $12 \%$ who had clinic-based testing (8). Based on these findings, receipt of rapid test results tended to be moderate to high except in urgent care clinics with regular business hours.

\section{Linkage to care}

Six of the eight (6/8) systematic reviews assessed linkage to care although the definition of linkage to care varied among the reviews. Roberts et al. defined linkage to care as entry into medical care and found this occurred in $47 \%$ to $100 \%$ of those who were diagnosed with HIV from rapid tests (16). Mavedzenge et al. defined linkage to care as linkage to prevention, treatment and care services and concluded that data are insufficient to determine whether self-testing leads to timely linkage to care (18). Dibosa-Osadolor et al. found that rapid HIV testing resulted in a higher percentage of patients being appropriately linked to care compared to traditional HIV testing (21); however, exact percentages were not listed. Bateganya et al. did not provide a clear definition for linkage to care, but included studies that offered voluntary pre- and post-test counselling at home. Compared to those offered testing and counselling in a clinic, those tested at home were more likely to accept post-test counselling (17). In the updated review by Bateganya et al., $12 \%$ received post-test counselling from a clinic and $56 \%$ received post-test counselling at home (8). Most reviews acknowledged that information on linkage to care was sparse $(9,15,16)$.

See Table 2 for a summary of the acceptability, receipt of test results and linkage to care data.

\section{Table 2: Summary of acceptability, receipt of HIV test results and linkage to care with primary references}

\begin{tabular}{|c|c|c|c|}
\hline Reference & Acceptability & Receipt of HIV test results & Linkage to care \\
\hline $\begin{array}{l}\text { Bateganya (2007) } \\
\text { (17) }\end{array}$ & $\begin{array}{l}\text { Those randomized in optional testing } \\
\text { locations (including home-based testing) } \\
\text { were } 4.6 \text { times more likely to accept } \\
\text { voluntary counselling and testing than } \\
\text { those in the facility arm (RR } 4.695 \% \mathrm{Cl} \\
3.6-6.2 \text { ) (26). }\end{array}$ & $\begin{array}{l}\text { In the year where participants were } \\
\text { given the option to receive their HIV } \\
\text { test results at home, participants } \\
\text { were } 5.23 \text { times more likely to } \\
\text { receive their results than during the } \\
\text { year when results were available } \\
\text { only at the facility (OR } 5.2395 \% \mathrm{Cl} \\
4.02-6.8)(27) \text {. }\end{array}$ & $\begin{array}{l}\text { The definition for linkage } \\
\text { to care was unclear. It } \\
\text { appears that those who } \\
\text { received their results also } \\
\text { received post-test } \\
\text { counselling. }\end{array}$ \\
\hline $\begin{array}{l}\text { Bateganya (2010) } \\
\text { (8) }\end{array}$ & $\begin{array}{l}\text { Acceptability of pre-test counselling and } \\
\text { HIV test was } 12 \% \text { vs. } 57 \% \text { (optional } \\
\text { group) (26) }\end{array}$ & $\begin{array}{l}12 \% \text { received post-test counselling } \\
\text { and their test results from the local } \\
\text { clinic; } 56 \% \text { received results and } \\
\text { counselling at home (RR } 4.795 \% \mathrm{Cl} \\
3.62-6.21)(26) \text {. }\end{array}$ & $\begin{array}{l}\text { The definition for linkage } \\
\text { to care was unclear. It } \\
\text { appears that those who } \\
\text { received their results also } \\
\text { received post-test } \\
\text { counselling. }\end{array}$ \\
\hline $\begin{array}{l}\text { Dibosa-Osadolor } \\
(2010)(21)\end{array}$ & $\mathrm{N} / \mathrm{A}$ & $\mathrm{N} / \mathrm{A}$ & $\begin{array}{l}\text { Antibody rapid testing also } \\
\text { resulted in a higher } \\
\text { percentage of patients } \\
\text { being appropriately linked } \\
\text { to care (28-31). }\end{array}$ \\
\hline $\begin{array}{l}\text { Napierala } \\
\text { Mavedzenge (2013) }\end{array}$ & $\begin{array}{l}\text { Health workers from African countries } \\
\text { had high interest in self-testing } 73 \% \text { to } \\
79 \%(32-34) \text {. }\end{array}$ & $\mathrm{N} / \mathrm{A}$ & Insufficient data. \\
\hline
\end{tabular}




\begin{tabular}{|c|c|c|c|}
\hline (18) & $\begin{array}{l}\text { In US studies, emergency department } \\
\text { patients and } \text { MSM }^{2} \text { had high } \\
\text { acceptability ranging from } 83 \% \text { to } 89 \% \\
(35-37) \text {. }\end{array}$ & & \\
\hline Pant Pai (2007) (15) & $\begin{array}{l}\text { Overall acceptability: } 83 \% \text { to } 97 \% \text { (38- } \\
42) \text {. } \\
\text { No clear consensus on patient } \\
\text { preference for method of rapid tests } \\
\text { (e.g., blood-based over oral fluid based). }\end{array}$ & $\mathrm{N} / \mathrm{A}$ & $\begin{array}{l}\text { Details of linkages to care } \\
\text { and prevention were not } \\
\text { reported. }\end{array}$ \\
\hline Pant Pai (2013) (9) & $\begin{array}{l}\text { Overall acceptability: } 74 \% \text { to } 96 \% \text { for } \\
\text { both supervised and unsupervised } \\
\text { settings }(7,35,43-49) \text {. } \\
\text { Supervised settings: } 24 \% \text { to } 95 \% \\
\text { (7,35,43-47) } \\
\text { - } \quad \text { Urban MSM: } 74 \%(35) \\
\text { - } \quad \text { Emergency department: } 85 \%(7) \\
\text { - } \quad \text { Rapid HIV testing site: } 78 \%(45) \\
\text { - } \quad \text { General urban population: } 92 \% \\
\quad \text { (46,47) } \\
\text { - } \quad \text { Educated students: } 95 \%(44) \\
\text { - } \quad \text { HIV Clinic attendees: } 24 \%(43) \\
\text { Unsupervised settings: } 78 \% \text { to } 84 \% \\
\text { (48,49) } \\
\text { - } \quad \text { Non-monogamous MSM: } 84 \%(49) \\
\text { - Healthcare professionals: } 78 \%(48)\end{array}$ & $\mathrm{N} / \mathrm{A}$ & $\begin{array}{l}\text { Only one study in a US } \\
\text { unsupervised setting was } \\
\text { reported } \rightarrow 96 \% \text { of those } \\
\text { who test positive for HIV } \\
\text { would seek post-test } \\
\text { counselling (50). }\end{array}$ \\
\hline Roberts (2007) (16) & 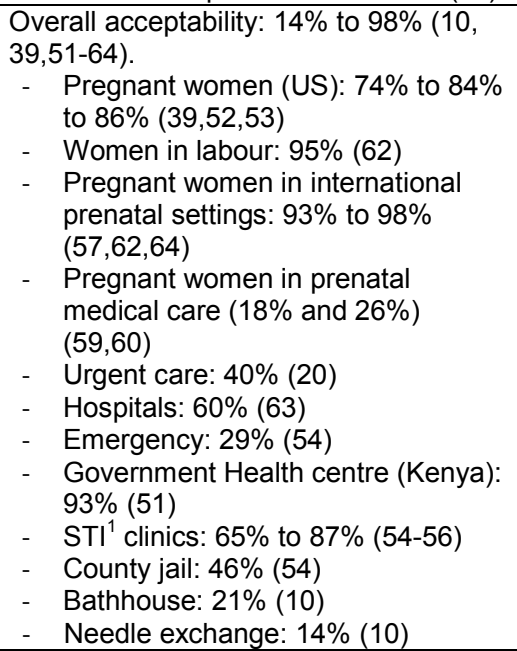 & $\begin{array}{l}\text { Overall receipt of HIV test results: } \\
27 \% \text { to } 100 \%(10,20,51,54- \\
56,59,63-69) . \\
\text { - } \quad \text { Hospital: } 95 \% \text { to } 100 \%(63,65) \\
\text { - } \quad \text { STI }{ }^{1} \text { clinic: } 89 \% \text { to } 99 \% \\
\quad(55,56,66) \\
\text { - } \quad \text { Urgent care: } 27 \%(20) \\
\text { - } \quad \text { Labour / delivery unit: } 68 \% \text { to } \\
\text { - } 94 \%(67) \\
\text { - Prenatal care: } 74 \% \text { and } 98 \% \\
\text { (59,64) } \\
\text { - } \text { Mobile site: } 99 \%(68) \\
\text { - Community settings (e.g., } \\
\text { homeless shelters, jail, } \\
\text { bathhouse, needle exchange): } \\
\text { 83\% to } 100 \%(10,54,69)\end{array}$ & $\begin{array}{l}\text { Overall: } 47 \% \text { to } 100 \% \text { (all } \\
\text { US studies) }(20,54,55 \text {, } \\
65) . \\
\text { Few studies examined } \\
\text { entry rates into medical } \\
\text { care in those who were } \\
\text { found to be HIV+ from } \\
\text { rapid tests. }\end{array}$ \\
\hline Turner (2013) (19) & $\begin{array}{l}\text { Overall acceptability: } 35 \% \text { to } 93 \% \text { ( } 70- \\
80) \text {. } \\
\text { Lowest acceptance rate was found in an } \\
\text { adolescent outpatient clinic ( } 35 \%)(73) \text {. } \\
\text { Highest acceptance rates found in } \\
\text { emergency departments ( } 83 \% \text { and } 93 \%) \\
(74,77) \text {. } \\
\text { When given the options of rapid and } \\
\text { traditional testing, youth selected rapid } \\
\text { tests } 70 \% \text { of the time }(73) \text {. }\end{array}$ & $\begin{array}{l}\text { Participants who chose a rapid test } \\
\text { were more likely to receive their } \\
\text { test results within the follow-up } \\
\text { period, compared with those who } \\
\text { chose traditional test }(91.3 \% \text { vs. } \\
46.7 \% \text {; OR } 1295 \% \mathrm{Cl} 3.98-36.14) \\
(73) \text {. } \\
100 \% \text { of youth aged } 13-17 \text { years } \\
\text { who accepted rapid testing } \\
\text { received their results }(77) \text {. }\end{array}$ & $\mathrm{N} / \mathrm{A}$ \\
\hline
\end{tabular}

STI = sexually transmitted infections

${ }^{2} \mathrm{MSM}=$ men who have sex with men 


\section{Cost-effectiveness}

Of the 17 modelling studies reviewed by Dibosa-Osadolor et al., seven studies addressed diagnostic testing for HIV detection. Four modelling studies specifically assessed rapid testing with immediate patient notification in a clinical setting. The authors concluded that HIV rapid testing was more cost-effective than traditional laboratorybased testing with immediate patient notification (21). However, the majority of the modelling studies of rapid testing reviewed were based on static models, which do not include time dependencies. This can potentially result in an overestimation of the cost-effectiveness of infectious diseases $(21,22)$. In this review, there was no information on the direct and indirect costs of rapid testing or on the cost per the quality-adjusted life-year gained.

\section{Discussion and conclusion}

Our rapid review of eight systematic reviews found that HIV rapid tests demonstrated generally high acceptability, especially among pregnant women; variability in receiving test results; and limited impact on linkage to care. One review found that rapid testing was cost-effective, but the studies were based on a static versus a dynamic model; therefore, further studies are warranted to determine the impact of rapid tests on linkage to care and its costeffectiveness.

The rapid review methodology is a fairly novel approach that has its strengths and limitations. The strength is that it is a rapid way to summarize evidence for decision-makers. In addition, the evidence is presented transparently, allowing users to assess the evidence and make informed decisions. However, there are a few limitations to consider when reviewing these results. The shortened timeframe of the rapid review process may miss studies that were not included in the reviews and therefore, may introduce bias through the absence of some relevant information. It may exclude recently published systematic reviews or those currently in press $(23,24)$. Moreover, data from some individual studies were cited more than once across the systematic reviews, which may inflate the confidence in the results presented in this rapid review $(24,25)$. Finally, the systematic reviews included studies from different countries and different types of HIV rapid tests; therefore, the results from this review may not be generalizable to other rapid tests or to the Canadian setting.

It appears that offering HIV rapid tests in settings is highly effective when test results can be readily obtained. This suggests that rapid HIV tests could decrease the proportion of individuals who are unaware of their HIV status and merits further study. Future research should compare effectiveness among different populations and settings, as well as explore ways to improve linkage to care. It would be useful to have a cost-effectiveness study based on a dynamic model.

\section{Acknowledgements}

The authors thank Margaret Gale-Rowe, John Kim, Lisa Pogany and Tom Wong for their review and input into the writing of this article. The authors would also like to thank Cindy Smalley and Elizabeth Dekens for their contributions to the literature search.

\section{Conflict of interest}

None.

\section{Funding}

This study was supported by the Public Health Agency of Canada.

\section{References}

(1) Public Health Agency of Canada Summary: Estimates of HIV prevalence and incidence in Canada, 2011. Ottawa: PHAC; 2011. http://www.phac-aspc.gc.ca/aids-sida/publication/survreport/estimat2011-eng.php 
(2) Anglemyer A, Horvath T, Rutherford G. Antiretroviral therapy for prevention of HIV transmission in HIV-discordant couples. Journal of American Medical Association. 2013; 310(15):1619.

(3) Fielden S, Lindegger M, Pederson H, McAloney C, Krajden M, Olgilvie G, et al. Evaluation findings from the pilot phase of BC's provincial point-of-care HIV testing program: The first 18 months. British Columbia: British Columbia Centre for Disease Control; 2013. http://www.bccdc.ca/NR/rdonlyres/OA26E458-1D17-4404-AB05-A81DE8B69260/0/CPS_POC_Program_Eval_Report_20130823.pdf

(4) SPOT: Find out where you stand - rapid, free and anonymous HIV testing. 2009. http://www.spottestmontreal.com/En/default.aspx.

(5) Public Health Agency of Canada. Human immunodeficiency virus HIV screening and testing guide. Ottawa: PHAC; 2013. http://www.catie.ca/sites/default/files/EN_HIV-Screening-Guide-2013.pdf

(6) Public Health Agency of Canada. Point-of-care HIV testing using rapid HIV test kits: Guidance for health-care professionals. Canada Communicable Disease Report. 2007;33S2.

(7) Gaydos CA, Hsieh Y, Harvey L, Burah A, Won H, Jett-Goheen M, et al. Will patients "opt in" to perform their own rapid HIV test in the emergency department? Annals of Emergency Medicine. 2011; 58(1 SUPPL.):S74-8.

(8) Bateganya M, Abdulwadud OA, Kiene SM. Home-based HIV voluntary counselling and testing (VCT) for improving uptake of HIV testing. Cochrane database of systematic reviews (Online). 2010;7.

(9) Pant Pai N, Sharma J, Shivkumar S, Pillay S, Vadnais C, Joseph L, et al. Supervised and unsupervised self-testing for HIV in high- and low-risk populations: A systematic review. PLoS Medicine. 2013; 10(4):e1001414.

(10) Spielberg F, Branson BM, Goldbaum GM, Lockhart D, Kurth A, Rossini A, et al. Choosing HIV counseling and testing strategies for outreach settings: A randomized trial. Journal of Acquired Immune Deficiency Syndromes. 2005 Mar 1; 38(3):348-55.

(11) Pai NP, Vadnais C, Denkinger C, Engel N, Pai M. Point-of-care testing for infectious diseases: Diversity, complexity, and barriers in low- and middle-income countries. PLoS Medicine. 2012; 9(9):e1001306.

(12) Arora DR, Maheshwari M, Arora B. Rapid point-of-care testing for detection of HIV and clinical monitoring. ISRN AIDS. 2013; 287269.

(13) Khangura S, Konnyu K, Cushman R, Grimshaw J, Moher D. Evidence summaries: The evolution of a rapid review approach. Systematic Reviews. 2012; 1(10).

(14) Shea BJ, Grimshaw JM, Wells GA, Boers M, Andersson N, Hamel C, et al. Development of AMSTAR: A measurement tool to assess the methodological quality of systematic reviews. BMC Medical Research Methodology. 2007; 7(10).

(15) Pai NP, Tulsky JP, Cohan D, Colford JM, Reingold AL. Rapid point-of-care HIV testing in pregnant women: A systematic review and meta-analysis. Tropical Medicine and International Health. 2007 Feb 2007; 12(2):162-73.

(16) Roberts KJ, Grusky O, Swanson AN. Outcomes of blood and oral fluid rapid HIV testing: A literature review, 2000 -2006 | abstract. AIDS Patient Care and STDs. 2007; 21(9):621-637.

(17) Bateganya M, Abdulwadud OA, Kiene SM. Home-based HIV voluntary counseling and testing in developing countries (review). Cochrane Review. 2007; (4):1-28.

(18) Napierala Mavedzenge S, Baggaley R, Corbett EL. A review of self-testing for HIV: Research and policy priorities in a new era of HIV prevention. Clinical Infectious Diseases. 2013; 57(1):126-138.

(19) Turner SD, Anderson K, Slater M, Quigley L, Dyck M, Guiang CB. Rapid point-of-care HIV testing in youth: A systematic review. Journal of Adolescent Health. 2013; 53(6):683-391.

(20) Centers for Disease Control and Prevention (CDC). Routinely recommended HIV testing at an urgent care clinic - Atlanta, GA, 2000. Morbidity \& Mortality Weekly Report (MMWR). 2001; 50(538-541).

(21) Dibosa-Osadolor O, Roberts T. Economic evaluation, human immunodeficiency virus infection and screening: A review and critical appraisal of economic studies. International Journal of Technology Assessment Health Care. 2010; 26(03):301-308.

(22) Welte R, Postma M, Leidl R, Kretzschmar M. Costs and effects of chlamydial screening: dynamic versus static modelling. Sexually Transmitted Diseases. 2005; 32(8):474-483.

(23) Watt A, Cameron A, Sturm L, Lathlean T, Babidge W, Blamey S, et al. Rapid reviews versus full systematic reviews: An inventory of current methods and practice in health technology assessment. International Journal of Technology Assessment in Health Care. 2008; 24(2).

(24) Ganann R, Ciliska D, Thomas H. Expediting systematic reviews: Methods and implications of rapid reviews. Implementation Science. 2010; 5(56).

(25) Moher D, Tetzlaff J, Tricco AC, Sampson M, Altman DG. Epidemiology and reporting characteristics of systematic reviews. PLoS Medicine. 2007; 4(3):e78. 
(26) Fylkesnes K, Siziya S. A randomized trial on acceptability of voluntary HIV counselling and testing. Tropical Medicine and International Health. 2004 May; 9(5):566-572.

(27) Wolff B, Nyanzi B, Katongole G, Ssesanga D, Ruberantwari A, Whitworth J. Evaluation of a home-based voluntary counselling and testing intervention in rural Uganda. Health Policy Plan. 2005 Mar; 20(2):109-116.

(28) Coco A. The cost-effectiveness of expanded testing for primary HIV infection. The Annals of Family Medicine. 2005; 3(5):391-399.

(29) Paltiel AD, Weinstein MC, Kimmel AD, Seage GR, Losina E, Zhang $H$, et al. Expanded screening for HIV in the United States - An analysis of cost-effectiveness. New England Journal of Medicine. 2005; 352(6):586-595.

(30) Paltiel AD. Expanded HIV screening in the United States: Effect on clinical outcomes, HIV transmission and costs. Annals of Internal Medicine. 2006; 145(11):797.

(31) Vickerman P, Watts C, Peeling RW, Mabey D, Alary M. Modelling the cost effectiveness of rapid point of care diagnostic tests for the control of HIV and other sexually transmitted infections among female sex workers. Sexually Transmitted Infections. 2006 Oct; 82(5):403-412.

(32) Blood Products Advisory Committee (BPAC) 2005 meeting dockets. http://www.fda.gov/ohrms/dockets/ac/cber05.html\#Blood.

(33) Feasibility and acceptability of HIV self-testing among health care workers: results of a pilot programme in hospitals in Kenya. 19th International AIDS Conference, Vienna, Austria; 2010.

(34) National AIDS and STD Control Programme. Preparedness for HIVIAIDS service delivery: the 2005 Kenya health workers survey. 2006. http://www.popcouncil.org/uploads/pdfs/horizons/KenyaHealthWorkerSurvey.pdf

(35) Carballo-Diéguez A, Frasca T, Dolezal C, Balan I. Will gay and bisexually active men at high risk of infection use over-thecounter rapid HIV tests to screen sexual partners? Journal of Sex Research. 2012; 49(4):379-387.

(36) Acceptability and ease of use of home self-testing for HIV among MSM. 19th Conference on Retroviruses and Opportunistic Infections CROI; 2012.

(37) Sharma A, Sullivan PS, Khosropour CM. Willingness to take a free home HIV Test and associated factors among internetusing men who have sex with men. Journal of the International Association of Providers of AIDS Care (Chic) 2011; 10(6):357-364.

(38) Malonza IM, Richardson BA, Kreiss JK, Bwayo JJ, Stewart GC. The effect of rapid HIV-1 testing on uptake of perinatal HIV-1 interventions: a randomized clinical trial. AIDS. 2003; 3;17(1):113-118.

(39) Rajegowda BK, Das BB, Lala R, Rao S, McNeeley DF. Expedited human immunodeficiency virus testing of mothers and new-borns with unknown HIV status at time of labor and delivery. Journal of Perinatal Medicine. 2005; 28(6):458-463.

(40) Rakgoasi SD. HIV Counselling and testing of pregnant women attending antenatal clinics in Botswana, 2001. Journal of Health, Population and Nutrition. 2005; 23(1):58-68.

(41) Shankar AV, Pisal H, Patil O, Joshi A, Suryavanshi N, Shrotri A, et al. Women's acceptability and husband's support of rapid HIV testing of pregnant women in India. AIDS Care. 2003; 15(6):871-874.

(42) Webber MP, Demas P, Enriquez E, Shanker R, Oleszko W, Beatrice ST, et al. Pilot study of expedited HIV-1 testing of women in labor at an inner-city hospital in New York City. American Journal of Perinatology. 2001; 18(1):49-58.

(43) Skolnik HS, Phillips KA, Binson D, Dilley JW. Deciding where and how to be tested for HIV: What matters most? JAIDS Journal of Acquired Immune Deficiency Syndromes. 2001; 27:292-300.

(44) Pant Pai N, Bhargava M, Sharma J, Balram B, Bois C, Joseph L, et al. Will HIV self-testing be accepted by low to medium risk educated populations? A pilot cross sectional study in students of McGill University. Canadian Journal of Infectious Diseases and Medical Microbiology: 21st Annual Canadian Conference on HIVIAIDS Research. 2012; 23(SA).

(45) Belza MJ, Rosales-Statkus ME, Hoyos J, Segura P, Ferreras E, Sanchez R, et al. Supervised blood-based self-sample collection and rapid test performance: a valuable alternative to the use of saliva by HIV testing programmes with no medical or nursing staff. Sexually Transmitted Infections. 2012 Apr; 88(3):218-221.

(46) Choko AT, Desmond N, Webb EL, Chavula K, Napierala-Mavedzenge S, Gaydos CA, et al. The uptake and accuracy of oral kits for HIV self-testing in high HIV prevalence setting: A cross-sectional feasibility study in Blantyre, Malawi. PLoS ONE. 2011; 8(10):e1001102.

(47) MacPherson P, Webb EL, Choko AT, Desmond N, Chavula K, Napierala Mavedzenge S, et al. Stigmatising attitudes among people offered home-based HIV testing and counselling in Blantyre, Malawi: Construction and analysis of a Stigma Scale. PloS One. 2011; 6(10):e26814.

(48) Kalibala S, Tun W, Muraah W, Cherutich P, Oweya E, Oluoch P. "Knowing myself first": feasibility of self-testing among health workers in Kenya. 2011. http://www.popcouncil.org/uploads/pdfs/2011HIV_KenyaHWSelfTesting.pdf. 
(49) Lee S, Roehler M, Miller T, Kardos K, Almeidasantos A, Gregg R. Development of an oral fluid self-test for HIV infection: evaluation in a population of unknown risk. AIDS 2012 XIX International AIDS Conference July 22-27. Washington, DC; 2012.

(50) Orasure Technologies. Final advisory committee briefing materials: Available for public release. OraQuick In-Home HIV Test. Washington D.C.: Food and Drug Administration, Blood Products Advisory Committee; 2012.

(51) Arthur GR, Ngatia G, Rachier C, Mutemi R, Odhiambo J, Gilks CF. The role for government health centers in provision of same-day voluntary HIV counseling and testing in Kenya. JAIDS Journal of Acquired Immune Deficiency Syndromes. 2005; 40(3):329-335.

(52) Centers for Disease Control and Prevention (CDC). Advancing HIV prevention: New strategies for a changing epidemic United States. Morbidity \& Mortality Weekly Report (MMWR). 2003; 52:329-332.

(53) Bulterys M, Jamieson DJ, O'Sullivan MJ, Cohen MH, et al. Rapid HIV-1 Testing During Labor: A Multicenter Study. Journal of the American Medical Association. 2004 Jul 14, 2004; 292(2):219-23.

(54) Kendrick SR, Kroc KA, Couture E, Weinstein RA. Comparison of point-of-care rapid HIV testing in three clinical venues. AIDS. 2004; 18(16):2208-2210.

(55) Kendrick SR, Kroc KA, Withum D, Rydman RJ, et al. Outcomes of offering rapid point-of-care HIV testing in a sexually transmitted disease clinic. JAIDS Journal of Acquired Immune Deficiency Syndromes. 2005 Feb 1, 2005; 38(2):142-146.

(56) Liang TS, Erbelding E, Jacob CA, Wicker H, et al. Rapid HIV Testing of Clients of a Mobile STD/HIV Clinic. AIDS Patient Care \& STDs. 2005 Apr 2005; 19(4):253-257.

(57) Nogueira SA, Lambert JS, Albuquerque AL, Rodrigues R, Reis S, Bornia R, et al. Assessment of a rapid HIV test strategy during labor: A pilot study from Rio de Janeiro, Brazil. Journal of Human Virology. 2001; 4(5):278-282.

(58) Phillips KA, Chen JL. Willingness to use instant home HIV tests: data from the California behavioral risk factor surveillance survey. American Journal of Preventive Medicine. 2003; 24(4):340-348.

(59) Pignatelli S, Simpore J, Pietra V, Ouedraogo L, Conombo G, Saleri N, et al. Factors predicting uptake of voluntary counselling and testing in a real-life setting in a mother-and-child center in Ouagadougou, Burkina Faso. Tropical Medicine \& International Health. 2006; 11(3):350-357.

(60) Shetty AK, Mhazo M, Moyo S, von Lieven A, Mateta P, Katzenstein DA, et al. The feasibility of voluntary counselling and HIV testing for pregnant women using community volunteers in Zimbabwe. International Journal of STD \& AIDS. 2005; 16(11):755-759.

(61) Smith LV, Rudy ET, Javanbakht M, Uniyal A, et al. Client satisfaction with rapid HIV testing: Comparison between an urban sexually transmitted disease clinic and a community-based testing center. AIDS Patient Care \& STDs. 2006 Oct 2006; 20(10):693.

(62) Viani RM, Araneta MRG, Ruiz-Calderon J, Hubbard P, et al. Perinatal HIV counseling and rapid testing in Tijuana, Baja California, Mexico: Seroprevalence and correlates of HIV infection. JAIDS Journal of Acquired Immune Deficiency Syndromes. 2006; 41(1):87-92.

(63) Wurcel A, Zaman T, Zhen S, Stone D. Acceptance of HIV antibody testing among inpatients and outpatients at a public health hospital: A study of rapid versus standard testing. AIDS Patient Care \& STDs. 2005; 19(8):499-505.

(64) Perez F, Mukotekwa T, Miller A, Orne-Gliemann J, Glenshaw M, Chitsike I, et al. Implementing a rural programme of prevention of mother-to-child transmission of HIV in Zimbabwe: first 18 months of experience. Tropical Medicine \& International Health. 2004; 9(7):774-783.

(65) Lubelchek R, Kroc K, Hota B, Sharief R, et al. The role of rapid vs conventional human immunodeficiency virus testing for inpatients: Effects on quality of care. Archives of Internal Medicine. 2005; 165(17):1956-60.

(66) Metcalf CA, Douglas JM, Malotte KC, Cross H, Dillon BA, Paul SM, et al. Relative efficacy of prevention counseling with rapid and standard HIV testing: A randomized controlled trial (RESPECT-2). Sexually Transmitted Diseases. 2005; 32(2):130-138.

(67) Forsyth BWC, Barringer SR, Walls TA, Landry ML, et al. Rapid HIV testing of women in labor: Too long a delay. JAIDS Journal of Acquired Immune Deficiency Syndromes. 2004; 35(2):151-154.

(68) Morin SF, Khumalo-Sakutukwa G, Charlebois E, Routh J, Fritz K, Lane T, et al. Removing barriers to knowing HIV status: Same-day mobile HIV testing in Zimbabwe. JAIDS Journal of Acquired Immune Deficiency Syndromes. 2006; 41(2):218224.

(69) Keenan PA, Keenan JM. Rapid HIV testing in urban outreach: A strategy for improving posttest counselling rates. AIDS Education and Prevention. 2001; 13(6):541-50.

(70) Batey S, Hogan VL, Cantor R, Hamlin CM, Ross-Davis K, Nevin C, et al. Short communication routine HIV testing in the emergency department: Assessment of patient perceptions. AIDS Research and Human Retroviruses. 2012; 28(4):352356 . 
(71) Christopoulos KA, Kaplan B, Dowdy D, Haller B, Nassos P, Roemer M, et al. Testing and linkage to care outcomes for a clinician-initiated rapid HIV testing program in an urban emergency department. AIDS Patient Care and STDs. 2011; 25(7):439-444.

(72) Freeman AE, Sattin RW, Miller KM, Dias JK, Wilde JA. Acceptance of rapid HIV screening in a southeastern emergency department. Academic Emergency Medicine. 2009; 16(11):1156-1164.

(73) Kowalczyk Mullins TL, Braverman PK, Dorn LD, Kollar LM, Kahn JA. Adolescent preferences for human immunodeficiency virus testing methods and impact of rapid tests on receipt of results. Journal of Adolescent Health. 2010; 46(2):162-168.

(74) Haines CJ, Uwazuoke K, Zussman B, Parrino T, Laguerre R, Foster J. Pediatric emergency department-based rapid HIV testing: Adolescent attitudes and preferences. Pediatric Emergency Care. 2011; 27(1):13-16.

(75) Mullins, Tanya L Kowalczyk,MD, MS, Kollar LM, MSN, Lehmann C, Kahn, Jessica A,MD, MPH. Changes in human immunodeficiency virus testing rates among urban adolescents after introduction of routine and rapid testing. Archives of Pediatric and Adolescent Medicine. 2010; 164(9):870.

(76) Kowalczyk Mullins TL, Braverman PK, Dorn LD, Kollar LM, Kahn JA. Adolescent preferences for human immunodeficiency virus testing methods and impact of rapid tests on receipt of results. Journal of Adolescent Health. 2010; 46(2):162-168.

(77) Sattin RW, Wilde JA, Freeman AE, Miller KM, Dias JK. Rapid HIV testing in a southeastern emergency department serving a semiurban-semirural adolescent and adult population. Annals of Emergency Medicine. 2011; 58(1 SUPPL.):S60S64.

(78) Swenson RR, Hadley WS, Houck CD, Dance SK, Brown LK. Who accepts a rapid HIV antibody test? The role of race/ethnicity and HIV risk behavior among community adolescents. Journal of Adolescent Health. 2011; 48(5):527-529.

(79) Minniear TD, Gilmore B, Arnold SR, Flynn PM, Knapp KM, Gaur AH. Implementation of and barriers to routine HIV screening for adolescents. Pediatrics. 2009; 124(4):1076-1084.

(80) Payne NS, Beckwith CG, Davis M, Flanigan T, Simmons EM, Crockett K, et al. Acceptance of HIV testing among AfricanAmerican college students at a historically black university in the south. Journal of the National Medical Association. 2006; 98(12):1912-1916. 